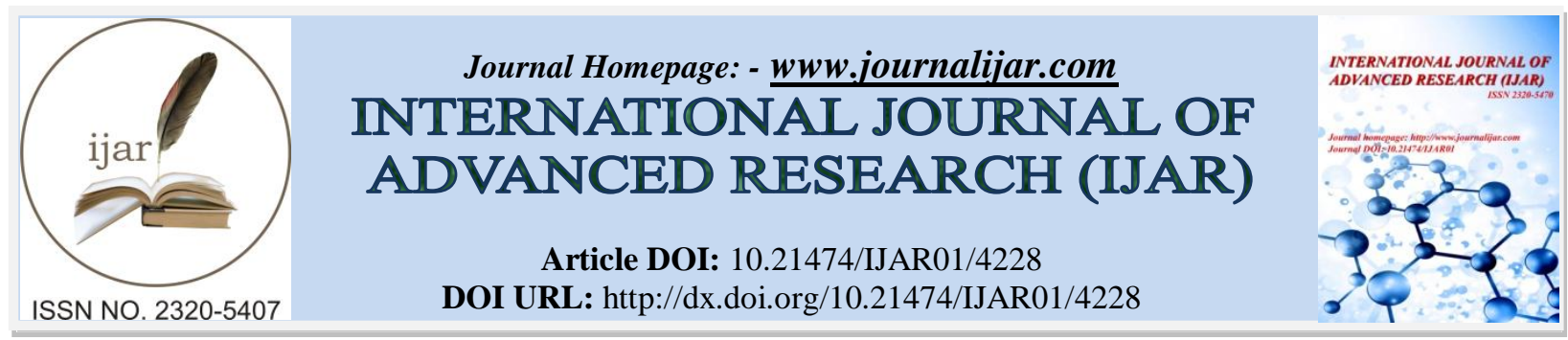

RESEARCH ARTICLE

\title{
THE ANTIBACTERIAL EFFECT OF ETHANOLIC EXTRACT OF Allium sativum ON BIOFILM FORMING Staphylococcus aureus WHICH CAUSE FOLLICULITIS.
}

Rawaa AlChalabi, Ruqia Mohammed, Rana Adnan andShatha AlBayati.

\section{Manuscript Info}

Manuscript History

Received: 19 March 2017

Final Accepted: 22 April 2017

Published: May 2017

\begin{abstract}
This study included isolation and identification of Staphylococcus aureus from folliculitis patients then detection the bacterial ability for biofilm formation, because biofilm play very important role in pathogensity and antibiotics resistance of bacteria. Fifty specimens have been collected, 47(94\%)specimens collected by swabbing gave positive culture and $3(6 \%)$ specimens gave negative culture .After Gram 44(93.6\%)isolates were Gram positive bacteria and $3(6.4 \%)$ isolates were Gram negative bacteria when identification of positive and negative bacterial isolates has been completed the results showed that $2(4.3 \%)$ isolates were Pseudomonas sp., 1(2.1\%) isolates was Klebseilla sp. and $44(93.6 \%)$ isolates were $S$.aureus. Thirty nine (88.6\%) isolates of $S$. aureus produced biofilm and only 5 (11.4\%) isolates not produced biofilm although isolates obtained from folliculitis patients and reflected resistance to antibiotics. Ciprofloxacin reflect high efficiency against $S$. aureus with inhibition zone $(26 \mathrm{~mm})$ while ethanolic extract of locally garlic which showed high inhibitive ability against S. aureus with inhibition zone (27mm).
\end{abstract}

Copy Right, IJAR, 2017,. All rights reserved.

\section{Introduction:-}

Medicinal plants are used in various tribal medicine due to minimal side effect and cost effectiveness.Garlic one of the oldest plants used in medicine ranks the highest of all the herbal remedies consumed for its health benefits. Scientific and clinical studies have shown that garlic can enhance immunity, protect against infection and inflammation and help lower the risk of cancer (Karwan ,2013 and Chekkiet al., 2014).In addition, garlic may be effective against drug-resistant bacteria, and research has revealed that as allicin digests in your body, it produces sulfonic acid, a compound that reacts with dangerous free radicals faster than any other known compound .In order to get the health benefits, the fresh clove must be crushed or chopped in order to stimulate the release of an enzyme called alliinase, which in turn catalyzes the formation of allicin(Tessemaet al., 2006 and Taylor,2013).

Folliculitis is defined histologically as the presence of inflammatory cells within the wall and ostia of the hair follicle, creating a follicular-based pustule. The type of inflammatory cells varies depending on the etiology of the folliculitis and/or the stage at which the biopsy specimen was obtained(Saegemanet al.,2017). When hair follicles are damaged, they may be invaded by viruses, bacteria and fungi, leading to infections such as folliculitis. Superficial folliculitis affects the upper part of the hair follicle and the skin directly next to the folliclewhile deep folliculitis affects the deeper portion of the follicle and can involve the entire hair follicle(Andre and Soares ,2015).Folliculitis is oftencaused by Staphylococcus aureus and may also be caused by viruses, fungi . Follicles are densest on your 
scalp, and they occur everywhere on your body except your palms, soles, lips and mucous membranes and the treatments receive for folliculitis depend on the type and severity of your condition(Otberget al., 2008 and Sillaniet al., 2010).

Folliculitis occurs in both sexes and in all ethnicities and age groups. The most superficial form of skin infection is staphylococcal folliculitis, manifested by minute erythematous follicular pustules without involvement of the surrounding skin. Gram-negative organisms that commonly cause folliculitis in this setting are Klebsiella sp., Pseudomonas sp. (Sharquieet al., 2012).Regardless of the causative agent, individual lesions of folliculitis may be asymptomatic, painful, or pruritic. Lesions often heal spontaneously without scarring, although deep infection and excoriation may lead to scars. (Degitzet al., 2007 andTchernev,2011 ). Also, Candida may cause folliculitis in diabetics, the immunocompromised, and patients with chronic antibiotic therapy (eg, taking a tetracycline for acne vulgaris) .

Staphylococcus aureus are Gram-positive, catalase positive cocci belonging to the Staphylococcaceae family . They are approximately $0.5-1.5 \mu \mathrm{m}$ in diameter, non-motile, non-spore-forming, facultative anaerobes that usually form in clusters. Many strains produce staphylococcal enterotoxins, the super antigen toxic shock syndrome toxin (TSST1), and exfoliative toxins. Staphylococcus aureus are part of human flora, and are primarily found in the nose and skin(Chambers and Deleo ,2009).Staphylococcus aureus is a virulent pathogen that is currently the most common cause of infections in hospitalized patients. Staphylococcus aureus infection can involve any organ system. The success of Staphylococcus aureus as a pathogen and its ability to cause such a wide range of infections are the result of its extensive virulence factors. The increase in the resistance of this virulent pathogen to antibacterial agents, coupled with its increasing prevalence as a nosocomial pathogen, is of major concern(Liu,2010).

Biofilm is thin usually resistant layer of microorganisms (as bacteria) that form on and coat various surfaces(Bendouahet al., 2006). Staphylococcus aureus can produce a multilayered biofilm embedded within a glycocalyx or slime layer with heterogeneous protein expression Staphylococcus aureus biofilm mode of growth is tightly regulated by complex genetic factors. Host immune responses against persistent biofilm infections are largely ineffective and lead to chronic disease(Corriganet al., 2009).

\section{Materials and Methods:- Specimens Collection:-}

Specimens are collected by swabbing the involved areas of the skin. When pustules or vesicles are present, the roof or crust is removed with a sterile surgical blade. The pus or exudate is spread as thinly as possible on a clear glass slide for Gram staining. Specimens collected from patients of (Al- Yarmouk hospital and Al-Jabchi private Hospital during the period from Dec.-1-2016 to Mar.-1 -2017.

\section{Isolation of bacteria:-}

The swabswere spread on nutrient agar, mannitol salt agar and chromo agar plate. plates were incubated over night at $37^{\circ} \mathrm{C}$. This process was repeated several times for purity before use for further diagnosis steps.

\section{Detection the ability of bacteria for biofilm formation (Test tube Method):-}

By using Christensen method for detection the ability of bacterial isolates for biofilm formation, this method included inoculation $5 \mathrm{ml}$ of (Tryptcase soya broth) with particular isolates and incubated for 48 hours at $37{ }^{\circ} \mathrm{C}$, after that, the contents of the tubes were removed carefully and added the crystal violet stain (1\%) to each tube for 15 minutes then rinsed the tubes and let tubes to dry at room temperature $(20-25)^{\circ} \mathrm{C}$. The result was read by notice the formation of biofilm as a layer at the internal wall of tubes by naked eye and comprise with the negative control (tube contains Tsb medium without inoculation), thickness and color of layer consider a parameter of bacterial ability for biofilm formation(Christensen et al.,1982).

\section{Antibiotic sensitivity test:-}

Ten ml of nutrient broth medium was inoculated with bacterial isolate, and incubated at $37^{\circ} \mathrm{C}$ for 18 hours, transfer $0.1 \mathrm{ml}\left(1.5 * 10^{8} \mathrm{cell} / \mathrm{ml}\right)$ of freshly broth(Growth of bacteria was monitored by McFarland tube No. 5 turbidity standard, which as equivalent to bacterial concentration for inoculum $1.5 * 10^{8}$ organism / ml) to Muller-Hinton agar plate and streaked by sterile cotton swab three times by rotating the plate approximately $60 \mathrm{~mm}$ between streaking to ensure even distribution of the inoculum', the inoculated plates were placed at room temperature for 10 minutes to allow absorption of excess moisture, then antibiotic disks were applied by sterile forceps on the surface 
of plates and incubated at $37^{\circ} \mathrm{C}$ for 18 hours in an inverted position. After incubation, measured the diameter of inhibition zone(clear area around disks) by ruler which indicate the sensitivity of bacteria to that antibiotic and the result were compared with NCCLs(Atlas et al.,1995).

\section{Plant Extraction:-}

Garlic (Allium sativum) used in the present study was purchased from the local market of Baghdad, Iraq. The fresh garlic cloves were washed, peeled, sliced and sun dried for seven days. After drying, garlic was ground to fine powder by using an electric blender. $60 \mathrm{gm}$ powder of garlic was soaked in $300 \mathrm{ml}$ of $90 \%$ ethanol, The flask was incubated at room temperature for 5 days with shaking at $140 \mathrm{rpm}$. The crude extract was filtered by using 0.22 filter unit then concentrated in a rotary evaporator. Dried crude extract was dissolved in DMSO separately to the final concentration of $300 \mathrm{mg} / \mathrm{ml}(\mathrm{Gull}$ et al., 2012 ).

\section{Antibacterial activity by agar well diffusionMethod:-}

Agar well diffusion method is widely used to evaluate the antimicrobial activity of plants extracts . The agar plate surface is inoculated by spreading $100 \mu \mathrm{l}$ of the bacterial inoculum over the entire agar surface. Then, a hole with a diameter of 6 to $8 \mathrm{~mm}$ is punched aseptically with a sterile cork borer or a tip and (100 $\mu \mathrm{l})$ of the extract solution at desired concentration is introduced into the well. Then, agar plates are incubated overnight at $37^{\circ} \mathrm{C}$. The antibacterial activity determined by measurement of inhibition zone(Balouiriet al., 2015) .

\section{Results and Discussion:-}

Fifty specimens were collected from patients suffering from folliculitis by swabbing from two different hospitals in Baghdad. All the isolates were identified by using cultural, morphological and biochemical tests(Cruckshanket al., 1975).Results showed that 47 out of 50 gave positive culture as shown aa in table (1).

Table 1:- percentage of positive and negative culture of specimens.

\begin{tabular}{|l|c|c|c|}
\hline \multicolumn{2}{|c|}{ Culture } & No. of Isolates & Percentage $(\%)$ \\
\hline $1-$ & Positive & 47 & 96 \\
\hline $2-$ & Negative & 3 & 6 \\
\hline
\end{tabular}

At the beginning, microscopically examination showed that $3(6.4 \%)$ isolates out of 47 samples were classified as Gram negative bacteria and $44(93.6 \%)$ isolates as Gram positive bacteria. This result agreed with result reported by Suzanne and Maximo, (2009) who recorded bacterial skin infections are a common problem encountered in clinical practice range from superficial epidermal infections to life-threatening necrotizing fasciitis. Although most infections can be managed on an outpatient basis, physicians must remain alert for signs and symptoms indicative of a more serious infection requiring rapid evaluation and hospital admission and most bacterial infections are caused by gram-positive organisms, including Staphylococcus aureus, group and, Streptococcus viridans, and Enterococcus faecalis. Less common causes of infection include gram negative organisms such as, Pseudomonas sp., Aeromonas sp. and Klebseilla sp.

After performing biochemical tests and api 20 for bacterial isolates , results showed that 2(4.3\%) isolates was identified as Pseudomonas sp.,1 (2.1. \%) Klebsiella sp. and 44(93.6\%) isolates identified as Staphylococcus aureus as shown as in table(2). 
Table (2):- percentage of bacterial isolates.

\begin{tabular}{|c|c|c|c|c|c|c|}
\hline \multicolumn{2}{|c|}{ Staining pattern } & No. of & Percentage & Bacterial isolates & No. of & Percentage \\
\hline \multirow[t]{2}{*}{1.} & \multirow[t]{2}{*}{ G- VE } & \multirow[t]{2}{*}{3} & \multirow[t]{2}{*}{6.4} & Pseudomonas sp. & 2 & 4.3 \\
\hline & & & & Klebsiellasp. & 1 & 2.1 \\
\hline 2. & $\mathrm{G}+\mathrm{VE}$ & 44 & 93.6 & Staphylococcus. aureus & 44 & 93.6 \\
\hline
\end{tabular}

This result is compatible with result recorded by Raza et al., (1996) they found that skin diseases can be caused by viruses, bacteria, fungi, or parasites and the most common bacterial skin pathogens is Staphylococcus aureus. Also, Findley and Grice, (2014) reported that specific microbes in skin disease, but whose pathogenesis may be complicated by microbial community interactions and/or host-microbe interactions. The specific microbes strongly associated include Staphylococcus aureus, Propionibacterium acnes, and Malassezia spp., all of which are known skin commensals but also exhibit pathogenic potential under certain conditions. There are well-characterized skin pathogens that have been definitively linked to dermatological disorders(Wang et al., 2013),.

\section{Biofilm Formation:-}

Test tube method used to detect ability of pathogenic Staphylococcus aureus isolates which isolated from skin of folliculitis patients for biofilm formation. The result illustrated in table (3) showed high percent of Staphylococcus . aureus isolates were able to form biofilm. 39 (88.6\%) Staphylococcus .aureus isolatesformed biofilm with different degree of thickness and only $5(11.4 \%)$ isolates unable to form biofilm .

Table 3:- percentage of biofilm formation by S. aureus isolates.

\begin{tabular}{|c|c|c|c|}
\hline \multicolumn{2}{|c|}{ S. aureus Isolates } & No. & Percentage(\%) \\
\hline 1. & Biofilm Former & 39 & 88.6 \\
\hline 2. & Biofilm Non-former & 5 & 11.4 \\
\hline
\end{tabular}

Nitsche-Schmitz et al., (2007)notice that microorganisms differ in it's ability to produce biofilm, thickness of biofilm differ according to the genus and species of producing bacteria, conditions like temperature, $\mathrm{pH}$ and type of folliculitis .The Staphylococcus aureus isolates formed biofilm with different thickness .Bacterial adhesion and subsequent colonization of surfaces are the first step toward biofilm formation . Biofilm consisted of microcolonies encased in extracellular polysaccharide material which formed under selected conditions (Olsonet al.,2002;Anderson et al.,2007).

The biofilmdevelops on both living surfaces and artificial implants whichallow the bacteria to persist for long period by establishment of dormant reservoir of pathogens, re-emergence of bacteria from this reservoir might be the source of recurrent infection(Deleoet al., 2010). Staphylococcus aureus represents the most common bacteria caused skin diseases with posses high ability to produce biofilm which enable them to find safe haven and subvert clearance by innate host response. Because of the matrix of biofilm modify the environment of adherent cells by concentrating nutrients and protecting the cells from surfactant, biocides, phagocytic cells and antibiotic are generally not very effective against organism embedded in biofilm. Cells form biofilm express properties distinct from plank tonic cells which increased resistance to antimicrobial agents. Biofilm formed by Staphylococcus aureus significantly enhances antibiotic resistance by inhibiting the penetration of antibiotics, resulting in an increasingly serious situation( Yan et al., 2016 andSuviet al., 2017)

\section{Antibiotics Sensitivity:-}

Antibiotics are biochemical compounds naturally produced by certain types of microorganism (bacteria and fungi) that inhibit the growth or kill other microorganism( David,2013). The emergence of resistance of bacteria to antibiotics is a common phenomenonwhich considered major problem reflects evolutionary processes that take place during antibiotic therapy. The antibiotic treatment may select for bacterial strains with physiologically or genetically enhanced capacity to survive high doses of antibiotics. Under certain conditions, it may result in preferential growth of resistant bacteria, while growth of susceptible bacteria is inhibited by the drug( Rhee and Gardiner ,2004andOcampo et al., 2014).In this study the effect of antibiotics on Staphylococcus aureus isolates 
were tested by using standard disk diffusion method and results were obtained compared with the NCCLs .Results illustrated in tables (4) and figure (1) .

Table 4:-The percentage of antibiotics resistance of $S$. aureus isolates

\begin{tabular}{|l|c|c|c|}
\hline \multicolumn{2}{|c|}{ Antibiotics } & \multicolumn{2}{c|}{ Resistance } \\
\cline { 3 - 4 } & & No. & Percentage (\%) \\
\hline Penicillin & P & $\mathbf{4 4}$ & $100 \%$ \\
\hline Cephalexin & CL & 44 & $100 \%$ \\
\hline Cefotaxime & CTX & 44 & $100 \%$ \\
\hline Vancomycin & VA & 41 & $93.2 \%$ \\
\hline Clindamycin & CD & 5 & $11.4 \%$ \\
\hline Tetracycline & TE & 44 & $100 \%$ \\
\hline Amoxicillin +Clavunic acid & AMC & 44 & $100 \%$ \\
\hline Nalidexic acid & NA & 44 & $100 \%$ \\
\hline Ciprofloxacin & CIP & 0 & $0 \%$ \\
\hline Rifampin & RA & 13 & $29.7 \%$ \\
\hline
\end{tabular}

Moreover the table (4),indicate rang of resistance of Staphylococcus aureus isolates which gave very high resistance percentage to penicillin (100\%), (cephalexin 100\%, Cefotaxime $100 \%$, Tetracycline 100\% and Nalidexic acid $100 \%$ ) and gave varied resistance percentage to Amoxicillin +Clavunic acid (100\%), Vancomycin (93.2\%), Rifampin (29.7\%) and Clindamycin (11.4\%). while gave no resistance to ciprofloxacin . The prevalence of antibiotic resistance bacteria therapeutic problems that could be explained by several hypothesis such as influence of excessive in appropriate antibiotic used, antibiotic resistance among pathogenic bacteria that cause infections . Different types of antibiotics are discovered, some of them classified as broad spectrum antibiotic which effect on a wide range of bacteria (Gram positive and Gram negative), while others classified as narrow spectrum antibiotics effected on a limited type of microorganism (Tanet al., 2015).Certain types of bacteria are inherently resistant to the effect of particular antibiotic, this is called innate or intrinsic resistance, while resistance of other bacteria to antibiotic types considered as acquired resistance which may result through spontaneous mutation or the acquisition of new genetic information (Gill et al ., 2014).

The resistance of bacteria to particular antibiotic may result from mutation which change the components of bacterial cell or the bacteria may have the plasmid carrying genes encoded for these resistance or by transposons that encoded for resistance and have the ability to transfer to another plasmid which lack to the resistance property, the acquired of resistance between the bacterial cells may result from conjugation, or transformation or transduction . The determination of the resistance or sensitivity of bacterial isolates depends on the measurement of the diameter of inhibition zone. The results show that Staphylococcus aureus isolates gave very high resistance to $\beta$-lactam antibiotic because it produce $\beta$-lactamase. Also, S. aureus isolates reflect high resistance to cephalexin (100\%) which represent the first generation of cephalosporine and resist to cefotaxime with percentage (100\%),this resistance belong to the production of cephalosporinase .

Biofilm has an active role in bacterial pathogenicity because bacteria embedded in a matrix of host proteins and microbial slime, which provided a home for organism and promote increased drug resistance thus antibiotic less effective in biofilm cells than in planktonic cells. 


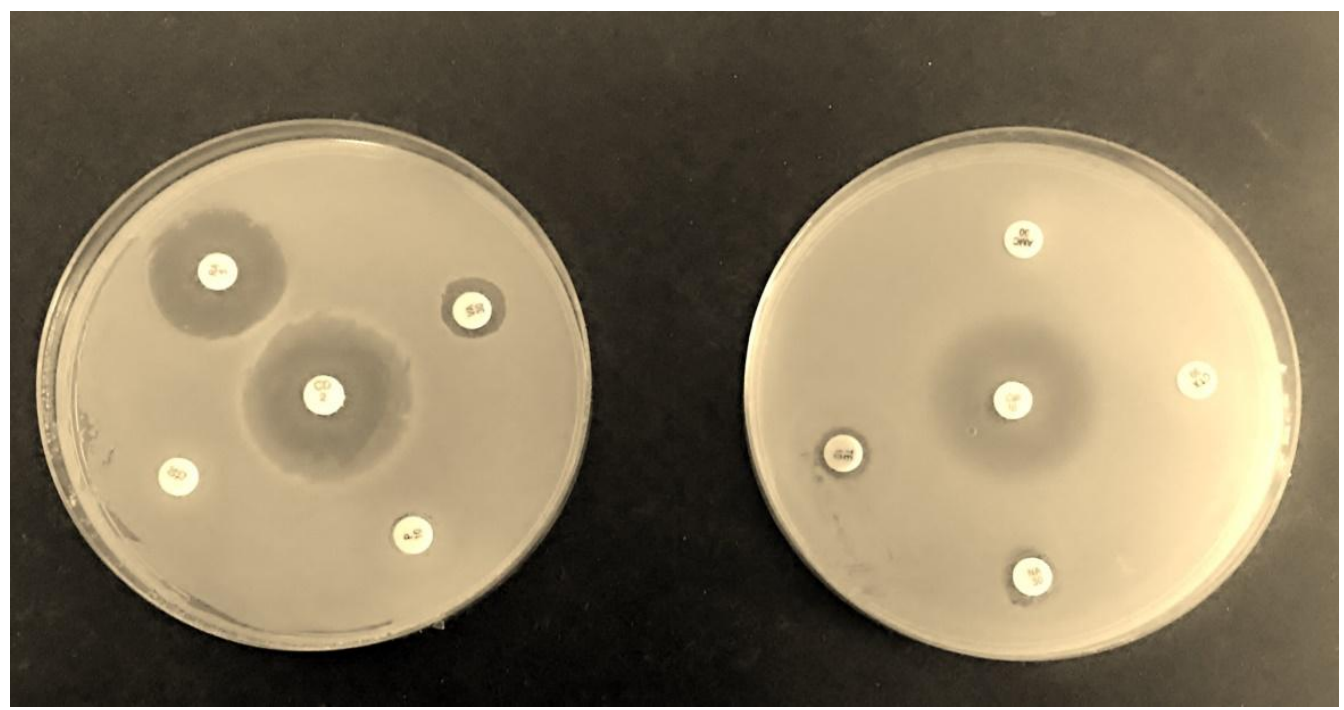

Figure 1:- Antibiotic sensitivity test by disk diffusion method.

Determinationof antibacterial activity of Allium sativumethanolic extract against S.aureus isolated from Folliculitis infection:-

Antibacterial activity of Allium sativumethanolic extract against Staphylococcus aureus isolated from folliculitis infections were diagnosed according to laboratory culture was determined by agar well diffusion method with different concentrations of Allium sativumethanolic extract. Results showed that ethanolic extract at concentration $(300 \mathrm{mg} / \mathrm{ml})$ have strong antibacterial activity against more efficient biofilm forming and multidrug-resistant Staphylococcus aureus isolates and the diameter of inhibition zone (23-28)mm as shown in figure (2) a while other concentration of extracts $(150,75 \mathrm{mg} / \mathrm{ml})$ have no antibacterial activity as shown in table (5). .The inhibition activity depends on concentrations (increased the concentrations of Allium sativumethanolic extract lead to increase the dimeter of the inhibition zone).

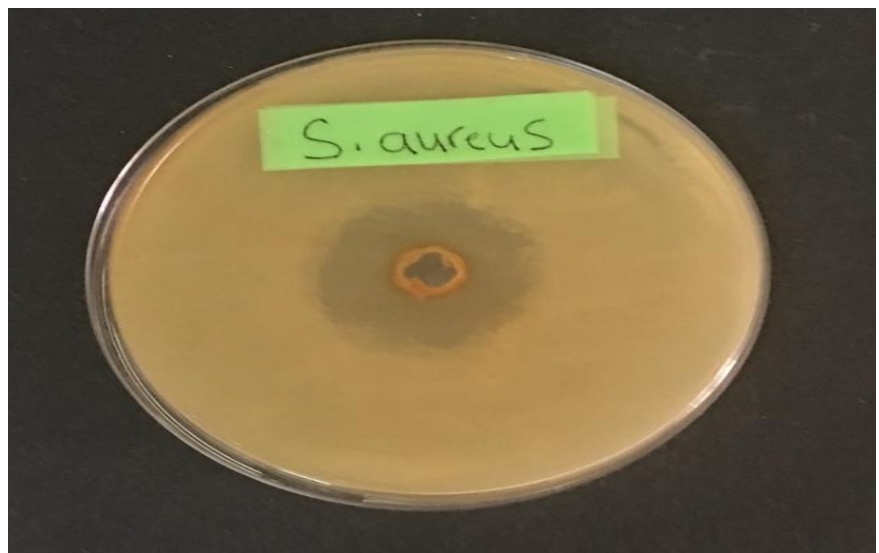

Figure 2:- Antibacterial activity of the Allium sativumethanolic extract

Table 5:-Antibacterial activity of the Allium sativumethanolic extract on more efficient biofilm forming Staphylococcus aureus isolates.

\begin{tabular}{|c|c|c|c|}
\hline \multirow{2}{*}{ Bacterial Isolates } & \multicolumn{3}{|c|}{ Concentrations of Allium sativumethanolic extract (mg $\backslash \mathrm{ml})$} \\
\cline { 2 - 4 } & $75 \mathrm{mg} \backslash \mathrm{ml}$ & $150 \mathrm{mg} \backslash \mathrm{ml}$ & $300 \mathrm{mg} \backslash \mathrm{ml}$ \\
\hline S1 & --- & ---- & 28 \\
\hline S2 & ---- & ---- & 25 \\
\hline S3 & ---- & ---- & 23 \\
\hline S4 & ----- & --- & 23 \\
\hline
\end{tabular}




\section{S: Staphylococcus aureus}

Garlic is a plant with various biological properties like antimicrobial, anti-cancer and antioxidant. Garlic extracts demonstrated activity against Gram negative and Gram-positive bacteria including species of Escherichia, Salmonella, Staphylococcus ,Streptococcus, Klebsiella, Proteus, Bacillus ,clostridium, Helicobacter pylori. Allicin is thiosulfate compound of garlic reported for its antibacterial activity. Allicin is proved to be anti-bacterial as it inhibitsRNA synthesis(Akintobiet al., 2013 and Desalegn,2014). The composition of Allium bulbs is complex. Garlic contains volatile oil (0.1-0.36\%), the major components are Sulphur compounds like alliin. It contains also proteins (amino acids, glutamyl peptides), , enzymes (alliinase, peroxidase, myronidase). Allicin is formed from alliin by the alliinase. It is considered that $1 \mathrm{mg}$ of alliin is equivalent to $0.45 \mathrm{mg}$ of allicin. Organo-sulfur compounds, flavonoids, sapogenins and saponins, selenium compounds and fructosamines have been recognized as the main bioactive principles in raw garlic and different garlic supplements (Fleischaueret al., 2000 and Viswanathanet al., 2014).Evidence from several investigations suggests that the biological and medical functions of garlic are mainly due to their high organo-sulphur compounds content Drugs derived from plants are effective, easily available, and less expensive and rarely have side effects. The practitioners of traditional and indigenous medicine rely mainly on medicinal plants and herbs for preparation of therapeutic substance. Initial screening for the potential antibacterial and antifungal compounds from plants may be performed by using the crude extracts (Durairajet al.,2010).

Furthermore, comparison between the inhibitory activity of the garlic extracts and antibiotics on Gram-positive Staphylococcus aureus revealed that ciprofloxacin had the high inhibitive activity with inhibition zone smaller than zone of extract against the susceptible $S$. aureus isolates. The variation in the size of the inhibition zone among the different isolates may be due to the content of the membranes, the permeability of allicin and other garlic constituents. There are a greater number of studies showing antimicrobial activity of garlic against bacteria, fungi, virus and human intestinal protozoan parasites.

\section{References:-}

1. Akintobi ,O.; Nwanze, J.;Ogele, J.; Idowu, A.; Onianwa, O. and I., Okonko (2013). Antimicrobial Activity of Allium sativum(Garlic) Extract against Some Selected Pathogenic Bacteria. Nature and Science .,11(1):1-7.

2. Anderson, B. N.; Albert, M. D.; Lina, M. N.; Kaoru, K.; Veronika, T.; Vogel, V.; Evgeni, V. S. and E. T. Wendy (2007).Weak rolling adhesion enhances bacterial surface colonization. J. Bacteriol.;189 (5):1794 - 1802.

3. Andre, M. and R.,Soares (2015). Effective Treatment of Decalvans: Azithromycin in Monotherapy. Hair : Therapy \& Transplantation.,5(1):1-4.

4. Atlas, R. M.(1995). Principle of microbiology 1st ed. Mosby - year bock Inc.

5. Bendouah, Z; Barbeau, J.; Hamad, W. and A., Desrosiers(2006). Biofilm formation by Staphylococcus aureus and Pseudomonas aeruginosa is associated with an unfavorable evolution after surgery for chronic sinusitis and nasal polyposis.Otolaryngol Head Neck Surg. ;134(6):991-996.

6. Balouiri, M.; Sadiki, M. and S Ibnsouda(2016).ethods for in vitro evaluating antimicrobial activity: A review Journal of Pharmaceutical Analysis.,6(2) : 71-79.

7. Chambers, H. and F., Deleo (2009). Waves of resistance: Staphylococcus aureus in the antibiotic era. Nat Rev Microbiol., 7: 629-641.

8. Chekki, R.; Snoussi, A.; Hamrouni, I and N., Bouzouita(2014).Chemical composition, antibacterial and antioxidant activities of Tunisian garlic (Allium sativum) essential oil and ethanol extract Mediterranean Journal of Chemistry ., 3(4), 947-956.

9. Christensen, G. D.; Simson, W. A.; Bisno. A. L. and E. H. Beachey (1982). Adherence of slime-producing strains of Staphylococcus epidermidisto smoth surface . Infect. Immun.; 37: 318-326.

10. Cruickshank, R.; Duguid, J. P. ;Mornion, B. P. and R. H. A. Swain (1975). Medical microbiology.Vol. 2 . 12th edchurchilllivingston ,Newyork

11. Corrigan, R.; Miajlovic, H. and T., Foster (2009). Surface proteins that promote adherence of Staphylococcus aureus to human desquamated nasal epithelial cells. BMC Microbiol., 30(4) :22-31.

12. David, D(2013). Natural Product Biosynthesis: Research on Nature's System for Diversifying Biologically Active Molecules. The Journal of Antibiotic.,70(5):69-80.

13. Degitz, K.; Placzek, M.; Borelli C. and G., Plewig (2007) Pathophysiology of acne. J DtschDermatolGes., 5: 316323.

14. Deleo, F.; Otto, M.; Kreiswirth, B. and H., Chambers (2010) Community-associated meticillinresistant Staphylococcus aureus. Lancet ., 375(5): 1557-1568.

15. Desalegn,A(2014). Antimicrobial Activity of Medicinal Plant Extracts and Their Synergistic Effect on Some Selected Pathogens. American Journal of Ethnomedicine ., 1( 1): 018-029. 
16. Durairaj,S.; Srinivasan, S. and P. ,Lakshmanaperumalsamy(2010). In vitro Antibacterial Activity and Stability of Garlic Extract at Different pH and Temperature. Electronic Journal of Biology, 6(4): 92-97.

17. Findley K, Grice EA (2014) The Skin Microbiome: A Focus on Pathogens and Their Association with Skin Disease. PLoSPathog 10(11): e1004436.

18. Fleischauer, A.; Poole, C. and L., Arab (2000). Garlic consumption and cancer prevention: meta-analyses of colorectal and stomach cancers. Am J Clin Nutr.;72(3):1047-1052.

19. Gill, E.; Franco, S.; Octavio, L. and H., Robert. (2015). Antibiotic adjuvants: diverse strategies for controlling drugresistant pathogens. Chemical Biology \& Drug Design., 85 (1): 56-78.

20. Gull,I.; Saeed,M.; Shaukat, H.; Shahbaz, M.; Aslam, Z.and M., Athar (2012). Inhibitory effect of Allium sativum and Zingiberofficinale extracts on clinical important drug resistant pathogenic bacteria. Annals of Clinical Microbiology and Antimicrobials 11(8):34-41.

21. Karwan, S(2013). Antibacterial Activity of Allium Sativum(Garlic) and Identification of Active Compound by GCMS Analysis. Int J Pharm Bio Sci 2013 Oct; 4(4): (B) 1071 - 1076.

22. Sharquie, K.; Noaimi, A. and Z., Mijthab (2012). Chronic Scalp Folliculitis versus Acne Vulgaris (Observational Case Series Study). J ClinExpDermatol Res.,3(3):53-56.

23. Liu,G(2010).Molecular Pathogenesis of Staphylococcus aureus InfectionPediatr Res. 65(5): 71R-77R.

24. Nitsche-Schmitz DP, Rohde M, Chhatwal GS (2007) Invasion mechanisms of Gram-positive pathogenic cocci. ThombHaemost 98: 488-496.

25. Ocampo, P.; Lázár, V.; Papp, B.; Arnoldini, M.; Abel, W.; Busa-Fekete, R.; Fekete, G.; Pál, C. and M., Ackermann (2014). "Antagonism between bacteriostatic and bactericidal antibiotics is prevalent". Antimicrobial Agents and Chemotherapy. 58 (8): 4573-4582.

26. Olson, M.; Howard, C.; Douglas, W.; Morck, A. and R., Ronald (2002). Biofilm bacteria : formation and comparative susceptibility to antibiotics. Can. J. Vet .Res .; 66(2): 86 -92.

27. Otberg, N.; Kang, H.; Alzolibani, A. and J., Shapiro (2008) Follicullitisdecalvans. Dermatologic Therapy 21: 238244.

28. Raza,M.; Baron ,S. and T., Galveston (1996). Medical Microbiology. 4th edition

29. Rhee, K. and D., Gardiner (2004). Clinical relevance of bacteriostatic versus bactericidal activity in the treatment of gram-positive bacterial infections". Clin. Infect. Dis. ,39 (5): 755-6.

30. Saegeman, M.; Veroniek , D.; Van, M. and M., Britt (2017).Aeromonas Associated With Swimming Pool Folliculitis .Pediatric Infectious Disease Journal., 35(1): 118-129.

31. Sillani, C.; Bin, Z.; Ying, Z.; Zeming, C.; Jian, Y. and Z., Xingqi, (2010). Effective treatment of folliculitis decalvans using selected antimicrobial agents. Int J Trichol .,;2:20-30.

32. Suvi, M.; Darla, M.;Goeres, S.; Vuorela, P. and A., Fallarero(2017). Prevention of Staphylococcus aureus biofilm formation by antibiotics in 96-Microtiter Well Plates and Drip Flow Reactors: critical factors influencing outcomes. Scientific Reports.,7(4):1-10.

33. Suzanne, J. ;Templer, D.; Maximo, O. and M., Brito (2009). Bacterial Skin and Soft Tissue Infections.,Emerg Infect Dis .;12(4):1715-23.

34. Tan, S.; Yong, T. and A., Yvonne (2015). "Alexander Fleming (1881-1955): Discoverer of penicillin". Singapore Medical Journal., 56 (7): 366-367.

35. Taylor, P.(2013). Alternative natural sources for a new generation ofantibacterial agents. Int $\mathbf{J}$ Antimicrob Agents.;42(3):195-201.

36. Tchernev,G (2011).Folliculitis Perifolliculitis Capitis AbscedensSuffodiens Controlled With a Combination Therapy: Systemic Antibiosis (Metronidazole Plus Clindamycin), Dermatosurgical Approach., Indian J Dermatol. ;56(3): 318320 .

37. Tessema, B.; Mulu, A.; Kassu, A. and G., Yismaw (2006). An in vitro assessment of the antibacterial effect of garlic (Allium sativum) on bacterial isolates from wound infections. Ethiop Med J.,44(4):385-389.

38. Viswanathan, A.; Phadatare, G. and A., Mukne(2014).Antimycobacterial and Antibacterial Activity of Allium sativum Bulbs.,Indian J Pharm Sci.; 76(3): 256-261.

39. Wang, Y.; Kuo, S.; Shu, M.; Yu, J. and S., Huang (2013) Staphylococcus epidermidis in the human skin microbiome mediates fermentation to inhibit the growth of Propionibacterium acnes: implications of probiotics in acne vulgaris. ApplMicrobiolBiotechnol .,98: 411-424.

40. Yan, C.; Tangjuan, L.; Ke ,W.; Changchun, H. and S., Cai, (2016). Baicalein Inhibits Staphylococcus aureus Biofilm Formation and the Quorum Sensing System In Vitro. PLoS ONE 11(4):1-18. 